\title{
Proliferating or Interleukin 1-activated Human Vascular Smooth Muscle Cells Secrete Copious Interleukin 6
}

\author{
Harald Loppnow and Peter Libby \\ Department of Medicine, New England Medical Center, and United States Department of Agriculture Human \\ Nutrition Research Center on Aging, Tufts University School of Medicine, Boston, Massachusetts 02111
}

\begin{abstract}
The cells that make up blood vessel walls appear to participate actively in local immune and inflammatory responses, as well as in certain vascular diseases. We tested here whether smooth muscle cells (SMC) can produce the important inflammatory mediator IL6. Unstimulated SMC in vitro elaborated $5 \times 10^{3}$ pg recIL6/24h (i.e., biological activity equivalent to $5 \times 10^{3} \mathrm{pg}$ recombinant IL6 (reclL6), as determined in B9-assay with a recIL6 standard). Several pathophysiologically relevant factors augmented IL6 release from SMC including $10 \mu \mathrm{g}$ LPS/ $\mathrm{ml}\left(10^{4} \mathrm{pg}\right.$ recIL6), $10 \mathrm{ng}$ tumor necrosis factor $/ \mathrm{ml}\left(4 \times 10^{4} \mathrm{pg}\right.$ recIL6), and most notably $10 \mathrm{ng} \mathrm{IL1/ml}\left(\geq 3.2 \times 10^{5} \mathrm{pg}\right.$ recIL6). Production of IL6 activity corresponded to IL6 mRNA accumulation and de novo synthesis. SMC released newly synthesized IL6 rapidly, as little metabolically labeled material remained cell-associated. In supernatants of IL1stimulated SMC, IL6 accounted for as much as $4 \%$ of the secreted proteins.

In normal vessels SMC seldom divide, but SMC proliferation can occur in hypertension or during atherogenesis. We therefore tested the relationship between IL6 production and SMC proliferation in response to platelet-derived growth factor (PDGF) in vitro. Quiescent SMC released scant IL6 activity, whereas PDGF (1-100 ng/ml) produced concentration-dependent and coordinate enhancement of SMC proliferation and IL6 release (linear regression of growth vs. IL6 release yielded $r>0.9)$. IL6 itself neither stimulated nor inhibited SMC growth or IL6 production. Intact medial strips studied in short-term organoid culture produced large quantities of IL6, similar to the results obtained with cultured SMC. These findings illustrate a new function of vascular SMC by which these cells might participate in local immunoregulation and in the pathogenesis of various important vascular diseases as well as in inflammatory responses generally. (J. Clin. Invest. 1990. 85:731-738.) IL1 • SMC • cytokines • vasculitis • atherosclerosis
\end{abstract}

\section{Introduction}

Localized host defense reactions and pathways of immunopathologic tissue damage often involve substantial alterations in the functions of blood vessels. Recent evidence suggests

Address reprint requests to Dr. H. Loppnow, Department of Medicine, Tufts University School of Medicine, 711 Washington St., Boston, MA 02111.

Received for publication 5 June 1989 and in revised form 1 September 1989.

J. Clin. Invest.

(C) The American Society for Clinical Investigation, Inc.

0021-9738/90/03/0731/08 \$2.00

Volume 85, March 1990, 731-738 heretofore unsuspected active participation of both major cell types of the vascular wall, endothelium, and smooth muscle, in many immune and inflammatory responses. For example, these cells can both respond to and produce certain mediators of immunity and inflammation, e.g., the cytokine ILl (1-4). In addition to its well known systemic effects, ILl can participate in activation of $T$ lymphocytes, alter the hemostatic balance of endothelial cells $(\mathrm{EC})^{1}(5,6)$, promote leukocyte adherence to endothelia $(7,8)$, and augment the production of various mediators by vascular cells (e.g., prostanoids, platelet-activating factor, and IL1 itself) (9-12).

IL6, another pleiotropic cytokine originally described as a variety of biological activities (13-15), is a major regulator of the acute phase response (16) and stimulates lymphocyte proliferation, as well as differentiation of and antibody production by B cells (17). Other possible actions of IL6 include modulation of the proliferation of nonlymphoid cells (18) or anti-viral activity (14). IL6 is generally considered a product of activated mononuclear phagocytes and fibroblasts, although vascular endothelium and other cell types can also produce this cytokine (19-21). Smooth muscle cells (SMC) by far outnumber $\mathrm{EC}$ in the types of blood vessels generally involved in regional immune responses (venules) or major vascular diseases (muscular arteries). Since SMC can generate certain immunostimulatory cytokines such as ILl or tumor necrosis factor (TNF) (22), we tested whether this cell type might also produce IL6, a more recently recognized $T$ and $B$ cell activator. We found that SMC can not only express the IL6 gene in a regulated manner, but that it constitutes a major secretory product of these cells after IL1 stimulation. Furthermore, proliferating SMCs exhibit increased IL6 elaboration, which might contribute to activation of $\mathrm{T}$ lymphocytes found in atheromata or the angiocentric lymphomatoses (23-27). SMC-rich short-term organoid cultures of medial strips, not subjected to passage in cell culture, confirmed the ability of cultured human vascular SMC to secrete large quantities of IL6. Our findings illustrate a novel pathway by which SMC might participate in local immunoregulation and in the pathogenesis of various important vascular diseases as well as in inflammatory responses generally.

\section{Methods}

Cell culture and stimulation of SMC. Human SMCs were isolated and characterized as described (11). The use of this usually discarded tissue was approved by the Human Investigation Review Committee of the New England Medical Center. Explant-derived SMCs (28) were maintained in DME containing 10\% FCS, antibiotics, L-glutamine, and

1. Abbreviations used in this paper: $\mathrm{EC}$, endothelial cell; IT, insulin and transferrin; PDS, plasma-derived serum; PDGF, platelet-derived growth factor; recIL6, recombinant IL6; SMC, smooth muscle cell; TNF, tumor necrosis factor. 
Hepes. The cells were used through passages 2-6. All culture media contained $<40 \mathrm{pg} / \mathrm{ml}$ of LPS as determined in our laboratory by chromogenic Limulus amebocyte assay. The cells exhibited the typical "hill and valley" growth morphology of SMC and many reacted with the monoclonal antibody HHF-35 which selectively recognizes muscle forms of actin but does not react with EC or fibroblasts (29). Cells were cultured at $20,000 \mathrm{SMC} / \mathrm{cm}^{2}$ and incubated $3 \mathrm{~d}$. The medium was replaced by fresh medium and stimuli were added for the indicated time.

Preparation of tissue cultures from human saphenous veins. Excess portions of human saphenous veins, harvested for coronary artery bypass surgery, were transported in heparinized blood of the donor and processed immediately. The veins were washed four times in DME to remove blood, and cut into portions of $1 \mathrm{~cm}$ in length. These pieces of veins were then cut longitudinally and again washed in DME. The connective tissue and the adventitia were stripped from the medial layer with two forceps. The remaining tissue, consisting of intima and media, was washed and cut into $2 \times 2$-mm portions. For each condition, four of these pieces were incubated together in insulin and transferrin-containing medium (IT-medium, described below) in 16-mm wells. After $48 \mathrm{~h}$, the tissues were carefully washed four times with fresh medium, and IT-medium with or without test stimuli was added for 24 h. The supernatants were harvested and centrifuged at $1,500 \mathrm{~g}$, FCS $(5 \%)$ was added, and samples were stored at $-20^{\circ} \mathrm{C}$ until analyzed by B9-assay. The tissue pieces were washed three times, IT-medium containing 5\% FCS was added, the tissue pieces were frozen for $2 \mathrm{~h}$ at $-20^{\circ} \mathrm{C}$, mechanically disrupted, cell debris was removed by centrifugation, and the clarified extracts were used for determination of cell-associated IL6.

Assay for IL6 activity. Cells of the hybridoma line B9, kindly provided by $\mathrm{L}$. A. Aarden $(30,31)$, were cultured in DME containing L-glutamine, antibiotics, 2-mercaptoethanol $\left(5 \times 10^{-5} \mathrm{M}\right)$, recombinant IL6 (recIL6), and 10\% FCS (B9-medium). Serial fourfold dilutions of samples were prepared in $100 \mu \mathrm{l}$ of B9-medium lacking recIL6. Cells were centrifuged twice in B9-medium without recIL6, adjusted to $40,000 \mathrm{cell} / \mathrm{ml}$, and $100 \mu \mathrm{l}$ of this cell suspension was added to $100 \mu \mathrm{l}$ of the diluted samples. The cultures were incubated for $72 \mathrm{~h}$, and exposed for the last $4 \mathrm{~h}$ of culture to $\left[{ }^{3} \mathrm{H}\right] \mathrm{TdR}(6.7 \mathrm{Ci} / \mathrm{mmol} ; 0.5 \mu \mathrm{Ci}$ per well). The cells were harvested onto glass fiber filters, using a cell harvester (model PHD; Cambridge Technology, Inc., Cambridge, MA) and analyzed in a liquid scintillation counter. Efficiency of counting was determined with an external standard and results were expressed as disintegrations per minute. The mean of triplicate cultures was determined and biological activity was calculated by probit analysis according to the method described for IL2 (32). The biological activity was defined using serial fourfold dilutions of samples and recIL6 (10 $\mathrm{ng} / \mathrm{ml}$ ) which was used as standard in every B9-assay.

Assay for mitogenic activity. SMC were cultured in 96-well flatbottom culture plates at a cell concentration of $1 \times 10^{5} / \mathrm{cm}^{2}$. After overnight incubation, medium was replaced by serum-free IT-medium (33), compounded from DME and Ham's F12 (1:1, vol:vol), supplemented with insulin $(1 \mu \mathrm{M})$, and transferrin $(5 \mu \mathrm{g} / \mathrm{ml})$. Cells were cultured for $48 \mathrm{~h}$, medium was replaced, and stimuli were added for 24 h. Parallel cultures were either analyzed for IL6 activity or exposed to $\left[{ }^{3} \mathrm{H}\right] \mathrm{TdR}$ for additional $24 \mathrm{~h}(6.7 \mathrm{Ci} / \mathrm{mmol} ; 0.5 \mu \mathrm{Ci}$ per well), cells were harvested, and thymidine incorporation was measured. Efficiency of counting was determined by use of an external standard.

Immunoprecipitation of metabolically labeled proteins. SMC $\left(20,000 / \mathrm{cm}^{2}\right)$ were cultured in $150-\mathrm{mm}$ dishes for $72 \mathrm{~h}$, washed twice in DME, and incubated with or without stimulus for $24 \mathrm{~h}$ in RPMI 1640 lacking unlabeled cysteine and methionine, containing L-glutamine, antibiotics, $5 \% \mathrm{FCS}$, and $100 \mu \mathrm{Ci} / \mathrm{ml}$ of $\operatorname{Tran}^{35} \mathrm{~S}$-label ${ }^{\mathrm{mm}}$ (ICN Biomedicals Inc., Irvine, CA). The supernatants were removed and equilibrated in immunoprecipitation buffer $(50 \mathrm{mM}$ Tris- $\mathrm{HCl}, 0.1 \%$ SDS, $1 \%$ sodium deoxycholate, $1 \% \mathrm{NP}-40,150 \mathrm{mM} \mathrm{NaCl}, 5 \mathrm{mM}$ EDTA, $20 \mu \mathrm{g} / \mathrm{ml}$ soybean trypsin inhibitor, $0.1 \mathrm{mM}$ PMSF, $5 \mu \mathrm{M}$ antipain, and $5 \mu \mathrm{M}$ leupeptin, $\mathrm{pH}$ 7.4) by centrifugation in a Centricon-3 device (Amicon Corp., Danvers, MA) at $4^{\circ} \mathrm{C}$. The samples (1 $\mathrm{ml})$ were "precleared" by addition of nonimmune rabbit serum $(10 \mu \mathrm{l})$, and absorption with fixed staphylococci (IgG-Sorb; The Enzyme Center, Malden, MA). After incubation for $2 \mathrm{~h}$, immune complexes were precipitated by centrifugation $\left(20 \mathrm{~min}, 1,500 \mathrm{~g}, 4^{\circ} \mathrm{C}\right)$. IL6 antibody $(10 \mu \mathrm{l})$ was added for $24 \mathrm{~h}$ and precipitated with fixed staphylococci. The pellets were washed three times with washing buffer $(50 \mathrm{mM}$ Tris- $\mathrm{HCl}, 0.02 \%$ SDS, $0.1 \% \mathrm{NP}-40,0.5 \mathrm{M} \mathrm{NaCl}, 5 \mathrm{mM}$ EDTA, 0.1 $\mathrm{mM}$ PMSF, $20 \mu \mathrm{g} / \mathrm{ml}$ soybean trypsin inhibitor, $5 \mu \mathrm{M}$ leupeptin, and 5 $\mu \mathrm{M}$ antipain, $\mathrm{pH} 7.4$ ), and once with $62.5 \mathrm{mM}$ Tris- $\mathrm{HCl}$. The pellets were then resuspended in SDS-PAGE sample buffer $(62.5 \mathrm{mM}$ Tris$\mathrm{HCl}, 2.3 \%$ SDS, $5 \%$ 2-mercaptoethanol, $10 \%$ glycerol, and $1 \mathrm{mg} / \mathrm{ml}$ bromphenol blue, $\mathrm{pH} \mathrm{7.4)}$ and heated at $95^{\circ} \mathrm{C}$ for $10 \mathrm{~min}$. Samples were centrifuged and the supernatant was electrophoresed on a $12.5 \%$ SDS-PAGE gel ( $30 \mathrm{~min}, 20 \mathrm{~mA} ; 2 \mathrm{~h}, 40 \mathrm{~mA})$. Gels were fixed in $10 \%$ glacial acid and $30 \%$ methanol $(1 \mathrm{~h})$, washed in water $(30 \mathrm{~min})$, treated with Fluorohance $(30 \mathrm{~min}$; Research Products International Corp., Mount Prospect, IL), dried for $2 \mathrm{~h}$, and fluorographed at $-70^{\circ} \mathrm{C}$ for $7 \mathrm{~d}$.

We quantified the amount of specifically precipitated proteins in supernatants of unstimulated LPS or IL1-stimulated cells. The supernatants were equilibrated and concentrated in immunoprecipitation buffer. Two samples $(10 \mu \mathrm{l})$ of each of these supernatants were added to $100 \mu \mathrm{l}$ immunoprecipitation buffer, respectively. Sample one was precipitated in $10 \%$ TCA, to quantify the total amount of de novo-produced protein. Sample two was precipitated with recIL6 antiserum (10 $\mu l)$ as described above, and run on a $12.5 \%$ SDS-PAGE gel. The gel was cut in $0.5 \mathrm{~cm}$ slices, each was solubilized in $30 \% \mathrm{H}_{2} \mathrm{O}_{2}$, and counted in a liquid scintillation counter. The radioactivity (disintegrations per minute) contained in the specific bands was used for calculation of specifically precipitated proteins.

Isolation of RNA and hybridization of Northern blots. SMC incubated with or without the stimuli were lysed in guanidine-isothiocyanate (4 M) (34), and RNA was extracted and precipitated twice after the protocol of Chomczynski and Sacchi (35). RNA of SMC $(10 \mu \mathrm{g} / \mathrm{ml})$ was applied to a $1.2 \%$ agarose gel containing formaldehyde (36), run at $35 \mathrm{~V}$ overnight, blotted to a nylon membrane by capillary transfer, and fixed by ultraviolet (UV) illumination for $2.5 \mathrm{~min}$ on each side. The membrane was prehybridized for $2 \mathrm{~h}$ and hybridized overnight with ${ }^{32}$ P-labeled IL6 cDNA $(13,14$, and 37). Autoradiography was performed using X-Omat AR film (Eastman Kodak Co., Rochester, NY).

\section{Results}

Production of IL6 activity by SMC. Human SMC cultured for $24 \mathrm{~h}$ without addition released some IL6 activity (Fig. $1 A$ ), but incubation with LPS, TNF, or platelet-derived growth factor (PDGF) enhanced IL6 production. IL1 greatly augmented IL6 production by SMC over a range of concentrations (Fig. $1 B$ ). In order to determine possible functions of IL6, we analyzed whether it induces its own production in SMC. Cells incubated with exogenous recIL6 for $6 \mathrm{~h}$, then washed and incubated for additional $18 \mathrm{~h}$ in fresh medium without recIL6 released no IL6 activity, although SMC likewise exposed to IL1 did secrete IL6 (data not shown). Addition of antibody raised against recIL6 (diluted 1:200) inhibited IL6 activity of LPS or IL1stimulated SMC supernatants in B9-assay by $99 \%$ (data not shown). Even maximally effective concentrations of LPS caused a 100-fold-less IL6 release from SMC than that elicited by IL1.

Time course of IL6 production. We analyzed the effect of various mediators on the kinetics of IL6 secretion over $144 \mathrm{~h}$ (Fig. 2). Release of IL6 activity from SMC began after $3 \mathrm{~h}$ of incubation with ILl (filled arrow) and increased continuously thereafter. LPS was a relatively weak inducer of IL6 through- 


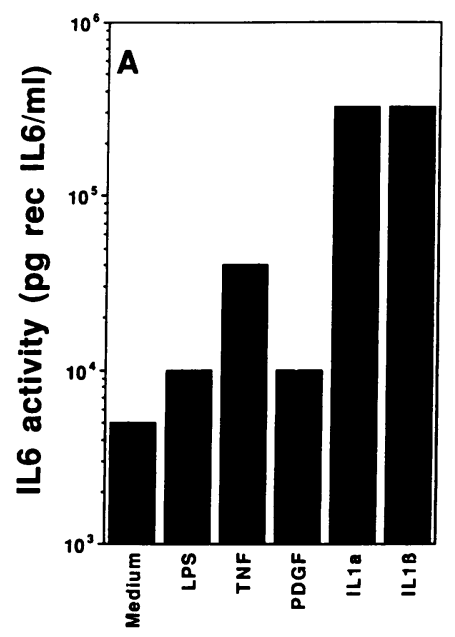

Stimuli

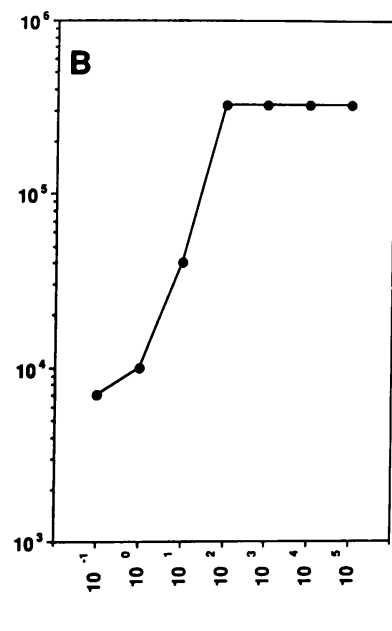

IL1 $\alpha(\mathrm{pg} / \mathrm{ml})$

Figure 1. (A) IL6 activity in supernatants of human SMC. Cells $\left(20,000 / \mathrm{cm}^{2}\right)$ were cultured $72 \mathrm{~h}$, medium was replaced, and stimuli were added for $24 \mathrm{~h}$. The concentration of LPS was $10 \mu \mathrm{g} / \mathrm{ml}$ and of all other stimuli $10 \mathrm{ng} / \mathrm{ml}$. (B) SMC were stimulated with various concentrations of IL1 $\alpha$. IL6 activity in supernatants was measured using the B9-assay.

out the entire time course, yielding maximal twofold increases compared with unstimulated SMC.

Influence of proliferation on IL6 production. Since SMC proliferation increases in certain pathological states, we investigated the relationship between growth state and IL6 elaboration by these cells. Recombinant PDGF (c-sis homodimer) produced concentration-dependent stimulation of $\left[{ }^{3} \mathrm{H}\right] \mathrm{TdR}$ incorporation, a valid index of human SMC multiplication under these conditions (38). IL6 production by these cells increased linearly as a function of proliferative rate (linear regression of growth vs. IL6 release yielded $r>0.9$ ) (Fig. 3). Experiments performed in a defined medium (IT-medium, Fig. 3, left) yielded a similar pattern as those performed in

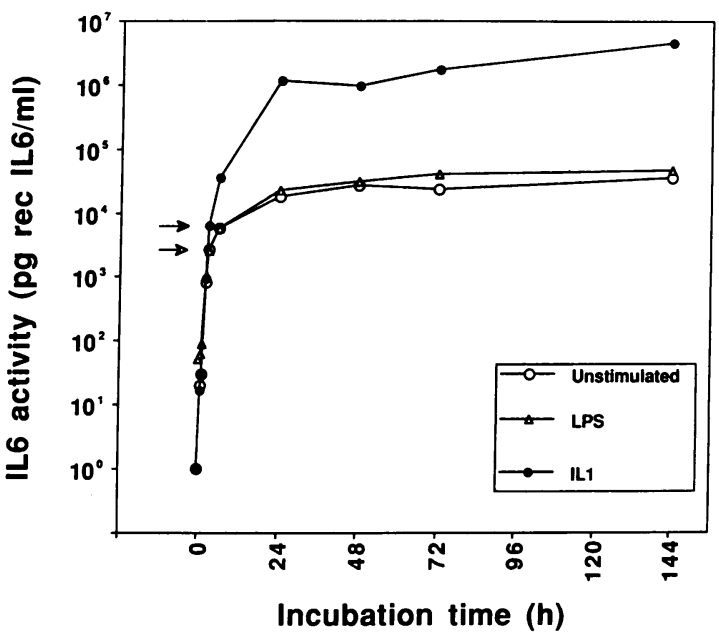

Figure 2. Time course of IL6 release. Unstimulated SMC or cells stimulated with LPS or IL1 were cultured in parallel for up to $144 \mathrm{~h}$. IL6 activity in supernatants was determined as above. The arrows mark the IL6 activity of IL1-stimulated (filled) or unstimulated SMC (open) after $3 \mathrm{~h}$ of culture.

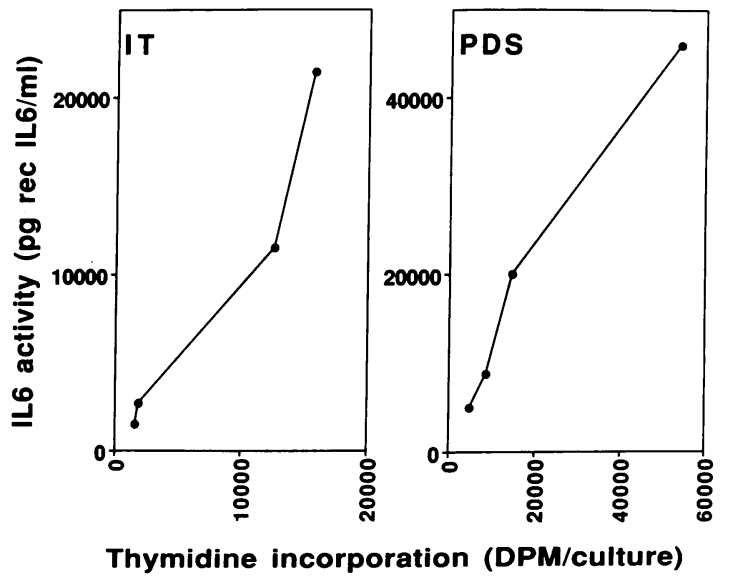

Figure 3. SMCs were cultured in FCS-containing medium at $100,000 / \mathrm{cm}^{2}$ for $24 \mathrm{~h}$, medium was replaced by three washes of ITmedium, and cultured for $48 \mathrm{~h}$. Parallel cultures were then incubated with or without PDGF (c-sis; $0,1 \mathrm{ng} / \mathrm{ml}, 10 \mathrm{ng} / \mathrm{ml}$, or $100 \mathrm{ng} / \mathrm{ml}$ ) in the designated medium (IT- or PDS-medium; PDS-medium is compounded of IT-medium and 10\% PDS) for further $24 \mathrm{~h}$ and either analyzed for IL6 in the B9-assay or thymidine incorporation (from 24-48 $\mathrm{h}$ after stimulation), as a measure for cell proliferation. The graph depicts the relationship between cell proliferation and IL6 release in the various conditions (from left to right: $0,1,10$, or 100 $\mathrm{ng} / \mathrm{ml}$ PDGF) in either IT- or PDS-containing medium.

medium containing plasma-derived serum (PDS, Fig. 3, right), which is low in mitogens but contains many undefined nutritive factors lacking in the serum-free IT-medium. Under conditions in which IL1 and PDGF produced approximately equivalent increases of cell number, IL6 release of recIL1treated SMC by far exceeded that of PDGF incubated cells (data not shown). Thus, ILl's inductive effect on IL6 production is not solely related to its proliferative action.

SMCs produce IL6 de novo. Metabolic labeling and immunoprecipitation experiments determined whether SMC released preformed or newly synthesized proteins. Unstimulated SMC released labeled proteins of the expected sizes (Fig. 4), consistent with the presence of biological IL6 activity, measured independently. IL1 prompted much greater elaboration of labeled IL6 proteins than did LPS, a finding also in agreement with our bioassay results. To elucidate the heterogeneity of specifically immunoprecipitated IL6 bands on SDS-PAGE, we performed experiments with tunicamycin, an inhibitor of $N$-glycosylation. This treatment virtually eliminated two more slowly migrating bands (arrowheads), an indication that these proteins are $\mathrm{N}$-glycosylated. The major precipitated protein might be unglycosylated or $O$-glycosylated, since it was not affected by this treatment. Cell lysates of SMC contained little IL6 protein, even after IL1 treatment.

Quantification of de novo IL6 synthesis and secretion. IL1stimulated SMC released high amounts of IL6 activity suggesting that IL6 is a major secretory product under these conditions. We explored this question by calculating the portion of IL6 in total biosynthetically labeled proteins released from IL1-stimulated SMC. IL6 accounted for about $4 \%$ of the secreted proteins (Table I). In contrast, IL1-stimulated EC produced only $<0.2 \%$ IL6 (data not shown).

Northern analysis of $m R N A$ derived from SMC. To investigate whether IL6 production is regulated at the level of translation or mRNA, we performed Northern analysis. Un- 


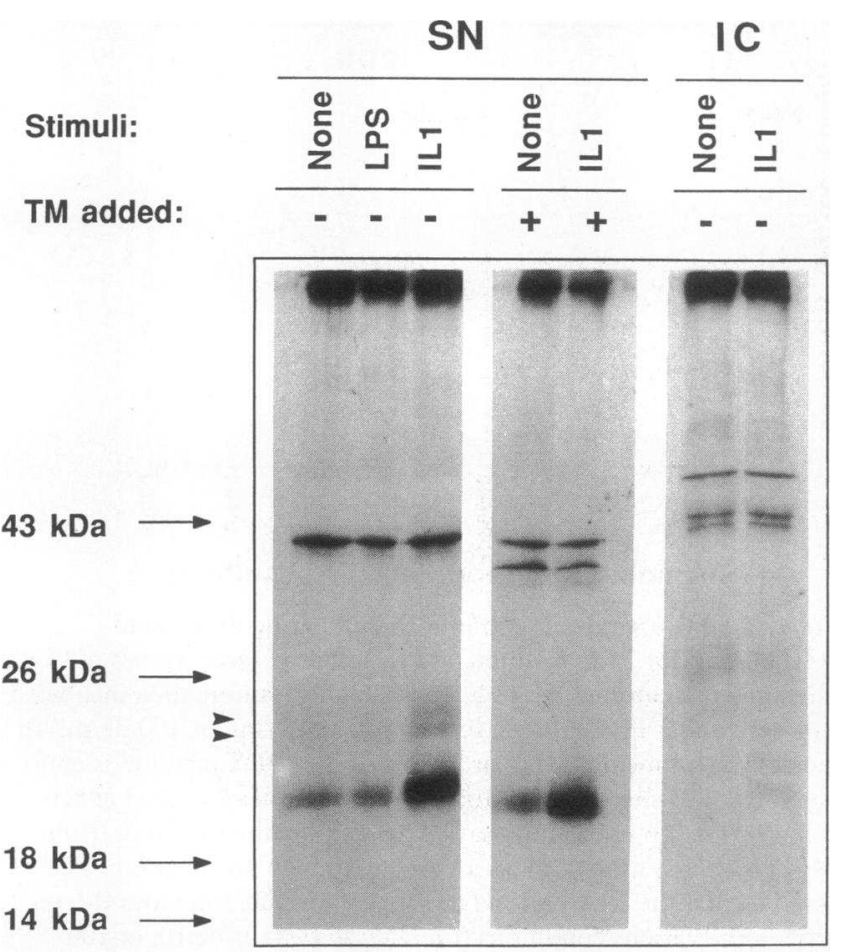

Figure 4. Radioimmunoprecipitation of biosynthetically labeled proteins derived from SMC supernatants or cell lysates $(2 \mu \mathrm{g} / \mathrm{ml}$ tunicamycin [TM] was added to some cultures). Unstimulated, LPS- (10 $\mu \mathrm{g} / \mathrm{ml})$ or ILl- $(10 \mathrm{ng} / \mathrm{ml})$ stimulated SMC were incubated $24 \mathrm{~h}$ in presence of $\left[{ }^{35} S\right]$ methionine-containing medium, lacking nonlabeled methionine. Supernatants (SN) or cell-lysates (IC) were equilibrated with precipitation buffer, precleared with normal rabbit serum, and precipitated with rabbit antihuman recIL6 serum (for details see Methods), run on a $12.5 \%$ SDS-PAGE gel, and visualized by autoradiography. The arrowheads indicate proteins that disappear after tunicamycin-treatment.

stimulated SMC lacked detectable IL6 mRNA (Fig. 5), as did LPS-, TNF-, or IL6-stimulated cells. SMC incubated with IL1, however, contained high levels of IL6 mRNA. Since SMC released IL6 activity basally or after incubation with LPS, failure to detect IL6 mRNA under these conditions probably reflects insufficient sensitivity of the Northern analysis. In su-

Table I. Quantification of De Novo-produced IL6

\begin{tabular}{lrrr}
\hline & \multicolumn{3}{c}{$\begin{array}{c}\text { Radioactivity } \\
\text { in samples of SMC treated } \\
\text { with different stimuli }\end{array}$} \\
\cline { 2 - 4 } Condition* & Unstimulated & \multicolumn{1}{c}{ LPS } & IL1 \\
\hline TCA-precipitated proteins & & & \\
(100\%) & 692,900 & $1,100,935$ & 878,708 \\
IL6 protein fraction of & 3,277 & 4,468 & 33,248 \\
SDS-PAGE gel & $(0.47 \%)^{\ddagger}$ & $(0.41 \%)$ & $(3.79 \%)$
\end{tabular}

* $10 \mu \mathrm{l}$ of radiolabeled supernatant either completely precipitated by TCA $(100 \%)$ or immunoprecipitated, and run on a $12.5 \%$ SDSPAGE gel. Lanes were sliced horizontally, and radioactivity of specific IL6 precipitates was detected.

₹ The percentage of specifically precipitated proteins.
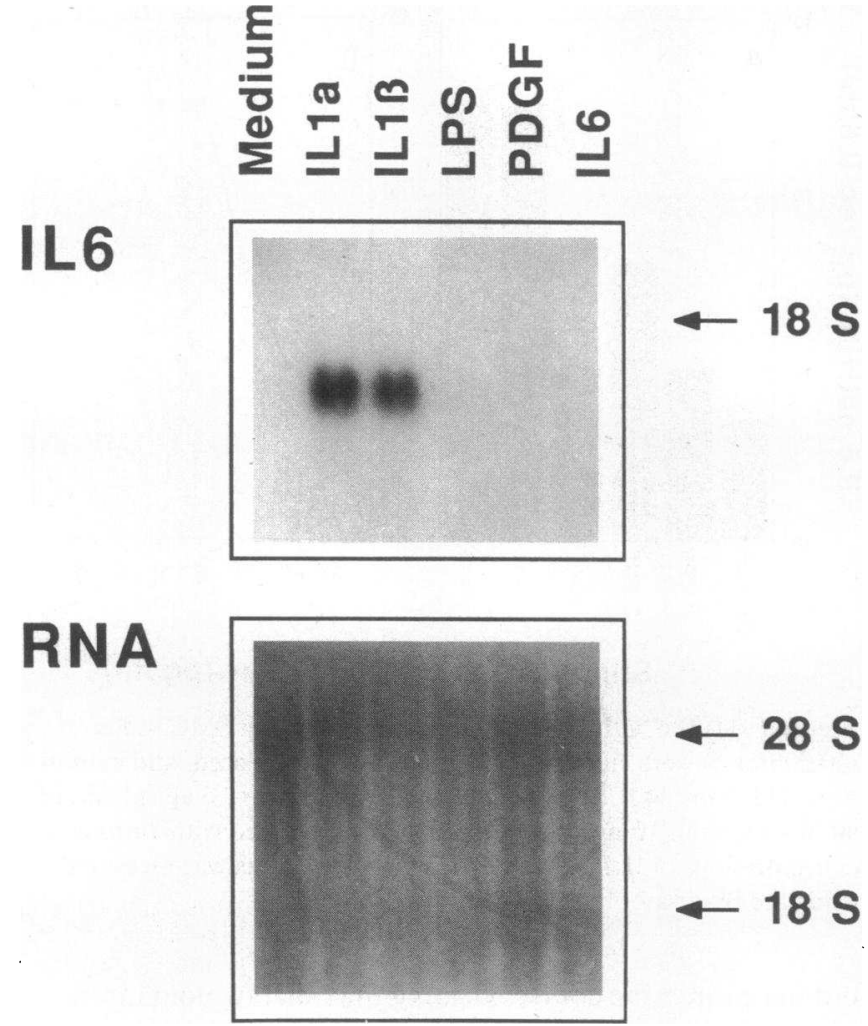

Figure 5. Accumulation of IL6 mRNA in SMC incubated with various stimuli for $24 \mathrm{~h}$. Except LPS $(10 \mu \mathrm{g} / \mathrm{ml})$, all stimuli were applied at $10 \mathrm{ng} / \mathrm{ml}$. Total RNA was isolated, $10 \mu \mathrm{g} /$ lane were separated by agarose gel electrophoresis, blotted to nylon membranes, and hybridized with IL6 probe (IL6) or directly visualized by UV illumination (RNA).

perinduction experiments with the protein synthesis inhibitor cycloheximide, unstimulated or LPS-stimulated SMC did contain IL6 mRNA (Fig. 6). Cycloheximide also markedly accentuated the IL6 signal in extracts of SMC treated with IL1.

Saphenous vein segments produce IL6 during short-term culture. The SMC shown above to produce IL6 were incubated two to six passages in vitro before study and might be in a "phenotypically modulated" state that differs from contractile SMC in vivo. To ascertain whether SMC in situ might also produce IL6 and to determine if they could produce high amounts as do cultured SMC, we approached the in vivo conditions as closely as possible by study of short-term organoid cultures of human saphenous veins. These tissues released significant IL6 activity even without stimulus (Table II). Addition of IL1, TNF, or LPS increased the IL6 release. The tissue extracts contained far less IL6 activity than the corresponding supernatants. The anti-recIL6 antiserum inhibited the IL6 activity in both supernatants and extracts by $\geq 92 \%$. In other experiments (data not shown) abrasion of the intima to remove completely the endothelium did not influence the pattern of IL6 production.

\section{Discussion}

Blood vessels figure prominently in a number of classic immunopathologic processes. Well-recognized examples include 


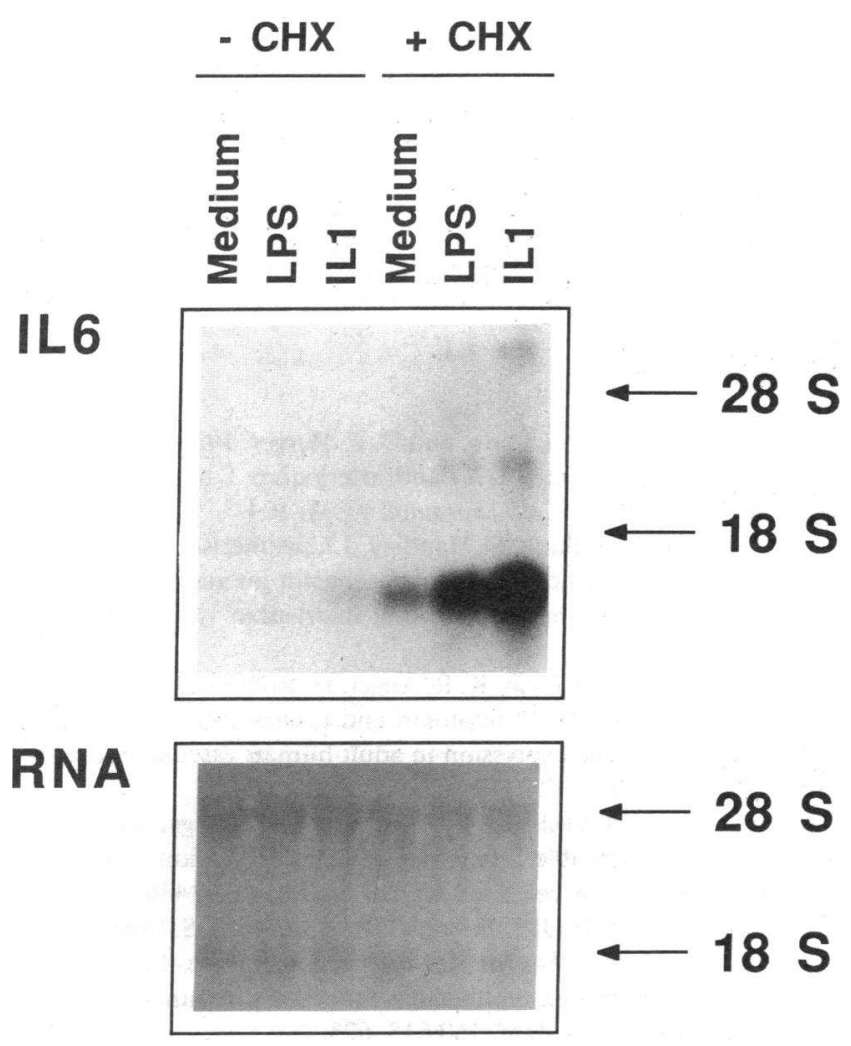

Figure 6. Superinduction of IL6 mRNA in SMC. Unstimulated, LPS- $(10 \mu \mathrm{g} / \mathrm{ml})$ or IL1- $(10 \mathrm{ng} / \mathrm{ml})$ stimulated SMCs were incubated in presence or absence of cycloheximide $(1 \mu \mathrm{g} / \mathrm{ml})$ for $24 \mathrm{~h}$, and total mRNA was isolated and treated as described in Fig. 5.

Table II. Saphenous Vein Strips Produce IL6 in Short-term Organoid Cultures

\begin{tabular}{|c|c|c|c|c|}
\hline \multirow[b]{3}{*}{ Stimulus ${ }^{8}$} & \multicolumn{4}{|c|}{$\begin{array}{l}\text { IL6 activity* in supernatants or lysates of human } \\
\text { saphenous vein tissue pieces incubated with or } \\
\text { without rabbit antihuman reclL6 antiserum (Ab) }\end{array}$} \\
\hline & \multicolumn{2}{|c|}{ Supernatants } & \multicolumn{2}{|c|}{ Cell-associated } \\
\hline & $-A b^{\ddagger}$ & $+A b$ & $-A b$ & $+\mathrm{Ab}$ \\
\hline \multirow[t]{2}{*}{ Unstimulated" } & 530,400 & 25,200 & 11,700 & 1,275 \\
\hline & 264,900 & 16,500 & 3,150 & 298 \\
\hline \multirow[t]{2}{*}{ ILl } & $3,693,300$ & 132,600 & 46,800 & 2,930 \\
\hline & $4,547,100$ & 132,600 & 40,800 & 2,072 \\
\hline \multirow[t]{2}{*}{ TNF } & $1,847,100$ & 71,100 & 40,800 & 1,465 \\
\hline & $1,399,500$ & 71,100 & 16,500 & 1,367 \\
\hline \multirow[t]{2}{*}{ LPS } & $1,305,900$ & 267,300 & 21,900 & 1,803 \\
\hline & $1,060,800$ & 43,800 & 28,800 & 2,734 \\
\hline
\end{tabular}

* IL6 activity was measured in the B9-assay. The IL6 activity was determined with respect to recIL6 standard $(10 \mathrm{ng} / \mathrm{ml})$.

${ }^{\ddagger}$ Rabbit antihuman recIL6 antiserum was applied at $1 / 1,000$ dilution $(\mathrm{Ab})$.

$\S$ The stimuli were applied at the following concentrations: IL1 $\alpha, 10$ $\mathrm{ng} / \mathrm{ml}$; TNF, $10 \mathrm{ng} / \mathrm{ml}$; and LPS of Salmonella abortus equi, $1 \mu \mathrm{g} / \mathrm{ml}$. "The presented data are results derived by probit analysis of two independent cultures studied at each condition. Each culture contained four tissue pieces. immune complex diseases, the Arthus and Shwartzman reactions, reaginic responses with increased vascular permeability, and delayed-type hypersensitivity characterized by diapedesis of leukocytes from venules (39-42). The protein mediators of immune and inflammatory responses, now known as cytokines, appear to produce many of their local actions by altering functions of vascular EC. Vessel wall cells not only serve as targets of cytokines, but also produce these mediators. For example, vascular EC and SMC can inducibly express genes for both isoforms of IL1 $(3,4)$. Under some circumstances, human SMC can express the TNF $\alpha$ gene (22). Vascular EC can also produce IL6 (19-21), a pleiotropic cytokine that unites a number of biological functions previously known by different names including B cell stimulatory factor- 2 (43), hepatic stimulatory factor (44), interferon $\beta_{2}(45,46), 26-\mathrm{kD}$ protein (47) or T cell activating factor (48).

We report here that vascular SMC, the most numerous cell type in macrovessels, also express the IL6 gene and secrete very high amounts of this mediator (ng/cell per $24 \mathrm{~h}$ ) in response to IL 1 , and to other pathophysiologically relevant stimuli to a lesser degree. The IL6 production in response to LPS might be mediated by IL1, however, preliminary experiments failed to provide evidence that autocrine IL1 is responsible for IL6 production induced by LPS. The levels of IL6 secreted by SMC by far exceed those produced by EC cultured under similar circumstances. For SMC, as in other cell types (49), IL1 appears to be the most effective stimulus for IL6 gene expression. Quantitative metabolic labeling and immunoprecipitation experiments established that IL6 comprised $\sim 4 \%$ of the proteins secreted by IL1-stimulated SMC. By contrast, in human EC isolated from the same type of vessel, IL6 accounted for $<0.2 \%$ of the total secreted protein even after IL1 treatment. Our data also indicate that SMC can modify newly synthesized IL 6 by $N$-glycosylation and secrete the cytokine without intracellular accumulation.

Upon prolonged culture, SMCs undergo a characteristic "phenotypic modulation" $(50,51)$ to a state that may resemble that of SMC in atheromata more closely than that of contractile SMC in the normal vessel. It was possible that the capacity to express IL6 genes depended on a phenotypic shift, as in the case of decay accelerating factor (52), which is expressed in atheromata and in passaged SMC in culture, but not in normal vascular tissue. We therefore examined production of IL6 activity in short-term organoid cultures of saphenous veins. SMC are by far the predominant cell type in these intimamedia strips. The tissues exhibited a pattern of basal and induced IL6 production very similar to that observed in the passaged cells in culture. These results support the concept that SMC in vivo might be important producers of IL6, since these tissues, not subjected to culture and passage, secreted large amounts of this mediator.

In contrast to IL1, IL6 lacks direct effects on EC and SMC functions tested. Within the walls of diseased blood vessels, locally produced IL6 might thus act to modulate the activities of lymphocytes rather than those of intrinsic vascular cells. IL1-induced IL6 gene expression by SMC could amplify IL1's stimulatory effects on $\mathrm{T}$ cell proliferation and account indirectly for B cell stimulation previously attributed to IL1. Lymphocytic infiltration characterizes a number of types of vasculitis. While phenotyping studies have been limited, leukocytic infiltrates in the walls of vasculitic vessels include both $B$ and $T$ cells $(27,53-56)$. Perivascular accumulation of $T$ cells charac- 
terize "angiocentric immunoproliferative" lesions such as those found in lymphomatoid granulomatosis. The reason for this congregation of hyperplastic $T$ cells around vessels is unknown. We propose that the copious amounts of the lymphocyte activator IL6 secreted by SMC might help to explain this pattern.

We further propose that SMC-derived IL6 may contribute to $T$ cell activation within regions of the evolving human atherosclerotic lesion. Although the necrotic cores of human atheromata contain lipid-laden macrophages (potential sources of the T cell comitogens IL1 and IL6), the active "shoulder" region of human atherosclerotic plaques contains large numbers of $\mathrm{T}$ lymphocytes and SMC but few if any mononuclear phagocytes $(25,26,57)$. The $T$ cells in this "shoulder" area appear activated, as they express IL2 receptors (56). Many of the SMC in the vicinity of the $T$ cells within atheromata bear MHC class II antigens. Immune interferon, a product of activated $T$ cells, is the only known inducer of class II HLA expression on human SMC (58). These findings all point to localization of activated T lymphocytes adjacent to SMC in areas of evolving human atheromata that lack abundant macrophages. In this situation, IL6 and/or IL1 secreted by SMC may well contribute to $\mathrm{T}$ cell activation.

In normal vessels, SMC divide little if at all. During atherogenesis, these cells, however, proliferate, probably due in part to abnormal mitogenic stimulation (59). We report here that cultured SMC dividing in response to PDGF augment their IL6 release. During formation of human atheromata, proliferating SMC may also release IL6, thereby furnishing one stimulus for $T$ cell activation. Increased production of inflammation-related proteins by growing SMC may represent a generalized response of these cells to mitogens as rat SMC secrete apolipoprotein $E(60)$ and rodent mesangial cells elaborate IL1 in a proliferation-dependent manner (61). Also, mitogenic stimuli augment IL6 (interferon $\beta_{2}$ ) production in mouse 3T3 cells (62) and FS-4 human fibroblasts (18).

In this regard, it is noteworthy that IL6 exhibited no mitogenic or growth-inhibitory effect on cultured SMC. Exposure to IL1 does, however, promote SMC proliferation. Some or all of this action may be due to stimulation of autocrine PDGFAA gene expression by these cells (63). Nonetheless, our experiments demonstrated that not all of IL1's stimulation of IL6 production by these cells is due to increased cell division.

Our finding that vascular SMC in in vitro or organoid cultures secrete large amounts of IL6 after activation increases our understanding of the possible mechanisms of $T$ cell activation within the blood-vessel wall during atherogenesis or other pathological situations. Stimulation by locally produced IL6 of B cell proliferation, differentiation, and antibody production may also contribute to the pathogenesis of autoimmune and other forms of vasculitis. In addition to these possible roles in pathogenesis of vascular diseases, IL6 derived from activated SMC may also participate in regional immune responses to invasive blood-borne infectious agents within vessel walls. Our results increase knowledge of the repertoire of immune and inflammatory functions of intrinsic cells of the blood-vessel wall and illustrate further the potential complexity of cytokine cascades at play in local host defense mechanisms and in pathology.

\section{Acknowledgments}

We thank Dr. L. A. Aarden for providing the B9 cell line, Dr. H. Brade for $S$. abortus equi LPS, Dr. C. A. Dinarello for recIL1 $\beta$, recIL6, and
recIL6 antibody, Dr. P. Lomedico for the recIL1 $\alpha$, as well as Drs. M. Revel, P. Seghal, and A. Zilberstein for the IL6 probe. The technical assistance of Mrs. M. W. Muszynski, Ms. E. Simon, and C. Galin is gratefully acknowledged. We also thank Mrs. J. Leonard and L. Joseph for perfect secretarial assistance.

This work was supported by grant Lo 385/1-1 to Dr. H. Loppnow from Deutsche Forschungsgemeinschaft and grant HL-34636 to Dr. Libby from the National Institutes of Health. Dr. Loppnow is supported by the Deutsche Forschungsgemeinschaft. Dr. Libby is an established Investigator of the American Heart Association.

\section{References}

1. Wagner, C. R., R. M. Vetto, and D. R. Burger. 1985. Expression of I-region-associated antigen (Ia) and interleukin 1 by subcultured human endothelial cells. Cell. Immunol. 93:91-104.

2. Nawroth, P. P., I. Bank, D. Handley, J. Cassimeris, L. Chess, and D. Stern. 1986. Tumor necrosis factor/cachectin interacts with endothelial cell receptors to induce release of interleukin 1. J. Exp. Med. 163:1363-1375.

3. Libby, P., J. M. Ordovàs, K. R. Auger, H. Robbins, L. K. Birinyi, and C. A. Dinarello. 1986. Endotoxin and tumor necrosis factor induce interleukin-1 gene expression in adult human vascular endothelial cells. Am. J. Pathol. 124:179-186.

4. Libby, P., J. M. Ordovas, L. K. Birinyi, K. R. Auger, and C. A. Dinarello. 1986. Inducible interleukin-1 Gene expression in human vascular smooth muscle cells. J. Clin. Invest. 78:1432-1438.

5. Bevilacqua, M. P., J. S. Pober, G. R. Majeau, R. S. Cotran, and M. A. Gimbrone, Jr. 1984. Interleukin 1 (IL-1) induces biosynthesis and cell surface expression of procoagulant activity in human vascular endothelial cells. J. Exp. Med. 160:618-623.

6. Nachman, R. L., K. A. Hajjar, R. L. Silverstein, and C. A. Dinarello. 1986. Interleukin 1 induces endothelial cell synthesis of plasminogen activator inhibitor. J. Exp. Med. 163:1595-1600.

7. Bevilacqua, M. P., J. S. Pober, G. R. Majeau, R. S. Cotran, and M. A. Gimbrone, Jr. 1985. Interleukin 1 acts on cultured human vascular endothelium to increase the adhesion of polymorphonuclear leukocytes, monocytes, and related leukocyte cell lines. J. Clin. Invest. 76:2003-2011.

8. Dustin, M. L., R. Rothlein, A. K. Bhan, C. A. Dinarello, and T. A. Springer. 1986. Induction by IL-1 and interferon-gamma: tissue distribution, biochemistry, and function of a natural adherence molecule (ICAM-1). J. Immunol. 137:245-254.

9. Albrightson, C. R., N. L. Baenziger, and P. Needleman. 1985. Exaggerated human vascular cell prostaglandin biosynthesis mediated by monocytes: role of monokines and interleukin 1. J. Immunol. 135:1872-1877.

10. Bussolino, F., F. Breviario, C. Tetta, M. Aglietta, A. Mantovani, and E. Dejana. 1986. Interleukin 1 stimulates platelet-activating factor production in cultured human endothelial cells. J. Clin. Invest. 77:2027-2033.

11. Warner, S. J. C., K. R. Auger, and P. Libby. 1987. Human interleukin 1 induces interleukin 1 gene expression in human vascular smooth muscle cells. J. Exp. Med. 165:1316-1331.

12. Warner, S. J. C., K. R. Auger, and P. Libby. 1987. Interleukin-1 induces interleukin-1. II. Recombinant human interleukin-1 induces interleukin-1 production by adult human vascular endothelial cells. $J$. Immunol. 139:1911-1917.

13. Sehgal, P. B., L. T. May, I. Tamm, and J. Vilcek. 1987. Human $\beta_{2}$ interferon and B-cell differentiation factor BSF-2 are identical. Science (Wash. DC). 235:731-732.

14. Zilberstein, A., R. Ruggieri, J. H. Korn, and M. Revel. 1986. Structure and expression of cDNA and genes for human interferonbeta-2, a distinct species inducible by growth-stimulatory cytokines. EMBO (Eur. Mol. Biol. Organ.) J. 5:2529-2537.

15. Yasukawa, K., T. Hirano, Y. Watanabe, K. Muratani, T. Matsuda, S. Nakai, and T. Kishimoto. 1987. Structure and expression of human B cell stimulatory factor-2 gene. EMBO (Eur. Mol. Biol. Organ.) J. 6:2939-2945. 
16. Gauldie, J., C. Richards, D. Harnish, P. Lansdorp, and H. Baumann. 1987. Interferon- $\beta_{2} /$ BSF-2 shares identity with monocyte derived hepatocyte-stimulating factor and regulates the major acute phase protein response in liver cells. Proc. Natl. Acad. Sci. USA. 84:7251-7255.

17. Kishimoto, T., and T. Hirano. 1988. Molecular regulation of B lymphocyte response. Annu. Rev. Immunol. 6:485-512.

18. Kohase, M., D. Henriksen-DeStefano, L. T. May, J. Vilcek, and P. B. Sehgal. 1986. Induction of $\beta-2$ interferon by tumor necrosis factor: A homeostatic mechanism in the control of cell proliferation. Cell. 45:659-666.

19. Jirik, F. R., T. J. Podor, T. Hirano, T. Kishimoto, D. J. Loskutoff, D. A. Carson, and M. Lotz. 1989. Bacterial lipopolysaccharides and inflammatory mediators augment IL6 secretion by human endothelial cells. J. Immunol. 142:144-147.

20. Sironi, M., F. Breviario, P. Proserpio, A. Biondi, A. Vecchi, J. Van Damme, E. Dejana, and A. Mantovani. 1989. ILI stimulates IL6 production in endothelial cells. J. Immunol. 142:549-553.

21. Loppnow, H., and P. Libby. 1989. Adult human vascular endothelial cells express the IL6 gene differentially in response to LPS or IL1. Cell. Immunol. 122:493-503.

22. Warner, S. J. C., and P. Libby. 1989. Human vascular smooth muscle cells: target for and source of tumor necrosis factor. J. Immunol. 142:100-109.

23. Jonasson, L., J. Holm, O. Skalli, G. Gabbiani, and G. K. Hansson. 1985. Expression of class II transplantation antigen on vascular smooth muscle cells in human atherosclerosis. J. Clin. Invest. 76:125-131.

24. Munro, J. M., and R. S. Cotran. 1988. The pathogenesis of atherosclerosis: atherogenesis and inflammation. Lab. Invest. 58:249261.

25. Gown, A. M., T. Tsukada, and R. Ross. 1986. Human atherosclerosis II. immunocytochemical analysis of the cellular composition of human atherosclerotic lesions. Am. J. Pathol. 125:191-207.

26. Emeson, E. E., and A. L. Robertson, Jr. 1989. T.lymphocytes in aortic and coronary intimas. Am. J. Pathol. 130:369-376.

27. Lipford, E. H., J. B. Margolick, Jr., D. L. Longo, A. S. Fauci, and E. S. Jaffe. 1988. Angiocentric immunoproliferative lesions: a clinicopathologic spectrum of post-thymic T-cell proliferations. Blood. 72:1674-1681.

28. Ross, R., and B. Kariya. 1980. Morphogenesis of vascular smooth muscle in atherosclerosis and cell structure. In Handbook of Physiology. The Cardiovascular System, Section 2. D. F. Bohr, A. P. Somlyo, and H. Y. Sparks, editors. American Physiological Society, Bethesda, MD. 69-91.

29. Tsukada, T., D. Tippens, D. Gordon, R. Ross, and A. M Gown. 1987. HHF35, a muscle-actin-specific monoclonal antibody. Am. J. Pathol. 127:51-60.

30. Aarden, L. A., E. R. De Groot, O. L. Schaap, and P. M. Lansdorp. 1987. Production of hybridoma growth factor by human monocytes. Eur. J. Immunol. 17:1411-1416.

31. Nijsten, M. W. N., E. R. De Groot, H. J. Ten Duis, H. J. Klasen, C. E. Hack, and L. A. Aarden. 1987. Serum levels of IL6 and acute phase responses. Lancet. ii:921.

32. Gillis, S., M. M. Ferm, W. Ou, and K. A. Smith. 1978. T-cell growth factor: parameters for production and a quantitative microassay for activity. J. Immunol. 120:2027-2032.

33. Libby, P., and K. V. O'Brien. 1983. Culture of quiescent vascular smooth muscle cells in a defined serum-free medium. J. Cell. Physiol. 115:217-223.

34. Chirgwin, J. M., A. E. Pryzbyla, R. J. Macdonald, and W. J. Rutter. 1979. Isolation of biologically active ribonucleic acid from sources enriched in ribonuclease. Biochemistry. 18:5294-5299.

35. Chomczynski, P., and N. Sacchi. 1987. Single step method of RNA isolation by acid guanidinium thiocyanate-phenol-chloroform extraction. Anal. Biochem. 162:156-159.

36. Maniatis, T., E. F. Fritsch, and J. Sambrook. 1982. Molecular cloning: A Laboratory Manual. Cold Spring Harbor Laboratory, Cold Spring Harbor, NY. 545 pp.
37. May, L. T., D. C. Helfgott, and P. B. Sehgal. 1986. Anti- $\beta$-interferon antibodies inhibit the increased expression of HLA-B7 mRNA in tumor necrosis factor-treated human fibroblasts: structural studies of the $\beta_{2}$-interferon involved. Proc. Natl. Acad. Sci. USA. 83:89578961.

38. Warner, S. J. C., G. B. Friedman, and P. Libby. 1989. Immune interferon inhibits proliferation and induces 2 - -5 '-oligoadenylate synthetase gene expression in human vascular smooth muscle cells. $J$. Clin. Invest. 83:1174-1182.

39. Movat, H. Z., C. E. Burrowes, M. I. Cybulski, and C. A. Dinarello. 1987. Acute inflammation and a Shwartzman-like reaction induced interleukin 1 and tumor necrosis factor: synergistic action of the cytokines in the induction of inflammation and microvascular injury. Am. J. Pathol. 129:463-476.

40. Cotran, R. S., M. A. Gimbrone, Jr., M. P. Bevilacqua, D. L. Mendrick, and J. S. Pober. 1986. Induction and detection of a human endothelial activation antigen in vivo. J. Exp. Med. 164:661-666.

41. Issekutz, T. B., J. M. Stoltz, and P. Van der Meide. 1988. Lymphocyte recruitment in delayed-type hypersensitivity. The role of IFN-gamma. J. Immunol. 140:2989-2993.

42. Pober, J. S., and R. S. Cotran. 1990. Cytokines and endothelial cell biology. Physiol. Rev. In press.

43. Hirano, T., K. Yasukawa, H. Harada, T. Taga, Y. Watanabe, T. Matsuda, S. Kashiwamura, K. Nakajima, K. Koyama, A. Iwamatsu, S. Tsunasawa, F. Sakiyama, H. Matsui, Y. Takahara, T. Taniguchi, and T. Kishimoto. 1986. Complementary DNA for a novel human interleukin (BSF-2) that induces B lymphocytes to produce immunoglobulin. Nature (Lond.). 324:73-76.

44. Ritchie, D. G., and G. M. Fuller. 1983. Hepatocyte stimulating factor: a monocyte derived acute phase regulatory protein. Ann. NY Acad. Sci. 408:490-502.

45. Weissenbach, J., Y. Chernajovsky, M. Zeevi, L. Shulmann, H. Soreq, U. Nir, D. Wallach, M. Perricaudet, P. Tiollais, and M. Revel 1980. Two interferon mRNAs in human fibroblasts: in vitro translation and Escherichia coli cloning studies. Proc. Natl. Acad. Sci. USA. 77:7152-7156

46. Sehgal, P. B., and A. D. Sagar. 1980. Heterogeneity of poly $(\mathrm{I}) \cdot \operatorname{poly}(\mathrm{C})$ induced human fibroblast interferon mRNA species. Nature (Lond.). 288:95-97.

47. Content, J., L. De Wit, D. Pierard, R. Derynck, E. De Clercq, and W. Fiers. 1982. Secretory proteins induced in human fibroblasts under conditions used for production of interferon $\gamma$. Proc. Natl. Acad. Sci. USA. 79:2768-2772.

48. Garman, R. D., and D. H. Raulet. 1987. Characterization of a novel murine T-cell activating factor. J. Immunol. 138:1121-1129.

49. Defilippi, P., P. Poupart, J. Tavernier, W. Fiers, and J. Content. 1987. Induction and regulation of mRNA encoding $26 \mathrm{kDa}$-protein in human cell lines treated with recombinant human tumor necrosis factor. Proc. Natl. Acad. Sci. USA. 84:4557-4561.

50. Chamley-Campbell, J. H., and G. R. Campbell. 1981. What controls smooth muscle phenotype? Atherosclerosis. 40:347-357.

51. Chamley-Campbell, J. H., G. R. Campbell, and R. Ross. 1981. Phenotype-dependent response of cultured aortic smooth muscle to serum mitogens. J. Cell Biol. 89:379-383.

52. Seifert, P. S., and G. K. Hansson. 1989. Decay-accelerating factor is expressed on vascular smooth muscle cells in human atherosclerotic lesions. J. Clin. Invest. 84:597-604.

53. Gephardt, G. N., M. Ahmad, and R. R. Tubbs. 1983. Pulmonary vasculitis (Wegener's granulomatosis). Immunohistochemical study of T and B cell markers. Am. J. Med. 74:700-704.

54. Moyer, C. F., J. D. Strandberg, and C. L. Reinisch. 1987. Systemic mononuclear-cell vasculitis in MRL/Mp-lpr/lpr mice. Am. J. Pathol. 127:229-242.

55. Tarkowski, A., R. Jonsson, R. Sanchez, L. Klareskog, and W. J. Koopman. 1988. Features of renal vasculitis in autoimmune MRL lpr/lpr mice: phenotypes and functional properties of infiltrating cells. Clin. Exp. Immunol. 72:91-97. 
56. Hansson, G. K., J. Holm, and L. Jonasson. 1989. Detection of activated $\mathrm{T}$ lymphocytes in the human atherosclerotic plaque. Am. J. Pathol. 135:169-175.

57. Jonasson, L., J. Holm, O. Skalli, G. Bonders, and G. K. Hansson. 1986. Regional accumulations of $\mathrm{T}$ cells, macrophages, and smooth muscle cells in the human atherosclerotic plaque. Arteriosclerosis. 6:131-138.

58. Warner, S. J. C., G. B. Friedman, and P. Libby. 1989. Regulation of major histocompatibility gene expression in cultured human vascular smooth muscle cells. Arteriosclerosis. 9:279-288.

59. Ross, R. 1986. The pathogenesis of atherosclerosis-an update. N. Engl. J. Med. 314:488-500.

60. Majack, R. A., C. K. Castle, L. V. Goodman, K. H. Weisgraber,
R. W. Mahley, E. M. Shooter, and P. J. Gebicke-Haerter. 1988. Expression of apolipoprotein $\mathrm{E}$ by cultured vascular smooth muscle cells is controlled by growth state. J. Cell Biol. 107:1207-1213.

61. Lovett, D. H., and A. Larsen. 1988. Cell cycle-dependent Interleukin 1 gene expression by cultured glomerular mesangial cells. $J$. Clin. Invest. 82:115-122.

62. Zullo, J. N., B. H. Cochran, A. S. Huang, and C. D. Stiles. 1985. Platelet-derived growth factor and double-stranded ribonucleic acids stimulate expression of the same genes in 3T3 cells. Cell. 43:793-800.

63. Raines, E. W., S. K. Dower, and R. Ross. 1989. Interleukin-1 mitogenic activity for fibroblasts and smooth muscle cells is due to PDGF-AA. Science (Wash. DC). 243:393-396. 